\title{
EFFECT OF SPRAYING WITH SOME AGRICULTURAL CHEMICALS ON INDUCING TOMATO PLANT RESISTANCE AGAINST TETRANYCHUS URTICAE (KOCH)
}

\author{
${ }^{1}$ Abdul Aziz A. Mustafa, ${ }^{2}$ Nabil M. T. Al Mallah \\ 1College Agriculture of /Talafar University \\ 2 Department of Plant Protection/Faculty of Agriculture and Forestry University of Al Mosul
}

Article information

Article history:

Received: $31 / 10 / 2021$

Accepted: 12/12/2021

Available: 12/31/2021

\section{Keywords:}

induced resistance, tomato variety, Tetranychus urticae, Agricultural chemicals.

DOI:

10.33899/magrj.2021.131985. 1147

Correspondence Email: abdulaziz.a.mustafa@uotelafer.ed u.iq

\section{ABSTRACT}

The results of the study of the effect of spraying with some agricultural chemicals on the seasonal activity of $\mathrm{T}$. urticae during the season 2019-2020 showed that the lowest general average of these numbers was when treated with the growth regulator Horm on 93.33 individuals/10 leaves, which differed significantly from all other spraying treatments as well as the comparison treatment (115.12 individuals/ 10 leaves) and that the lowest general average of these numbers was on $26 / 10$ reaching 19.80 individuals/10 leaves, and the local variety was significantly distinguished in achieving the lowest average of these numbers 104.09 individuals/10 leaves compared to the GS variety (132.47 individuals/10 leaves). The spraying treatments varied between them with regard to reducing or increasing the numbers of mites on leaves tomato is the GS variety and treatment with Horm, Fylloton and Grofalex led to a decrease in the averages of these numbers compared to the treatment of the control experiment, while the role of the rest of the treatments (Appetyzer, Acadian, Grofalex + Horm) was negative in this area, as it led to an increase in the sensitivity of these plants to infection. The GS variety was significantly superior in giving the highest content of carbohydrates, phenols and flavonoids, which amounted to $0.67 \mathrm{~g}, 12.91 \mathrm{mg}, 4.35 \mathrm{mg}$, respectively, compared with the local variety, while the local variety was significantly superior in the leaves content of proteins only (5.12 g) compared with the GS variety.

College of Agriculture and Forestry, University of Mosul.

This is an open access article under the CC BY 4.0 license (https://magrj.mosuljournals.com/ ).

\section{INTRODUCTION}

The Solanaceae family includes about 2000 species and 75 genera of different plants, including annuals and perennials. South America is the original home and from which it spread to other parts of the world. Most of the plants of this family are of economic importance because they are a major source of food or for extracting medicines or as ornamental plants, including tomatoes, potatoes and peppers as vegetables Basic (George,2011). The tomato, Lyopersicom esculantum, is one of the most important crops belonging to the Solanaceae family, and one of the most important major vegetable crops in the world and Iraq. It is one of the most popular vegetables in the world with an annual value of more than 90 billion US dollars (FAO, 2019). And mentioned in Litskas et al., (2019). In addition to the nearly threefold increase in the cultivated area compared 
to the last fifty years, or about five million hectares in 2015, the European Union countries are one of the most important tomato producers. More than $85 \%$ of the tomato is produced in open fields. Especially in the Mediterranean countries (Euro stat, 2019), and mentioned in Litskas et al., (2019).

The tomato crop is affected by many pests, the most important of which is the red two-spot spider mite Tetranychus urticac (kock) of the red spider mite family Tetranychidae of the order Parasitiformes, this species was previously known by many names, including the glass house spider mite and the yellow spider mite and the red spider mite (Gimens et al., 1994). This dream was first diagnosed by the scientist Koch in 1836 (Modal, 2006) and is one of the most famous lesions of the factor (Vacant, 2015). and cited by Litskas et al.,(2019).

The use of synthetic chemical acaricides is one of the most common methods used to control two-spot mites. One of the biggest problems with controlling it is its ability to quickly develop resistance resulting from the repeated use of these pesticides( Van Leeuwen et al., 2017). Thus, reducing the use of these manufactured pesticides is necessary to avoid the problem of resistance. In addition, the short life cycle, high fertility and its ability to develop resistance against many dream pesticides made its control difficult (Luczynski, et al., 1990), and the production of resistant varieties is an important and alternative method. In controlling mites as they are environmentally safe and have no side effects as well as their compatibility with other control methods within the integrated pest management programs (Adkisson, 2006). The resistance to mites has been recorded for more than 100 active chemicals. Various studies have shown that the resistance of tomato varieties to insects and mites depends on the density of glandular hairs and the chemical and physical properties of these hairs (Keskin and Kumral, 2015). Plant characteristics are direct plant defenses that affect the vitality of herbivorous pests such as mechanical resistance on the plant surface (such as hairs, thorns and leaf thickness) or the production of toxic chemicals such as terpenes, alkaloids, phenols, anthocyanins, ketones, which either kill, expel or impede Growth and development of these herbivores (Hanley, et al., 2007). For this and the importance of resistant varieties and methods of inducing resistance of tomato varieties to mites, the current study came.

\section{MATERIALS AND METHODS.}

The study was carried out on a farm dedicated to the cultivation of tomatoes belonging to one of the farmers in the area located on the Mosul-Dohuk road opposite the trade exchange yard during the 2020 agricultural season. To implement the study, the land allocated for the study was divided into equidistant slabs $(5.25 \times 4 \mathrm{~m})$ and between an experimental unit and another $1 \mathrm{~m}$ according to the RCBD complete block design and with three replications for each treatment. 4/21 for seedlings in the perennial field. The six treatments were randomly distributed to the experimental units, which included spraying five types of agricultural chemicals (growth regulators and fertilizers) in addition to the sixth treatment (treatment with two specific types of growth regulators). Then these chemicals were sprayed with different spray times that included treatments before and after flowering and based on the instructions for use of each substance, 
knowing that the spraying was using the concentrations recommended for use by the manufacturer. my agencies

Fylloton growth stimulator, 1.5-2 1/ha - 1.5-2 ml/1 water

Horm growth regulator 2 liters/ha $-2 \mathrm{ml} / \mathrm{l}$ water

Foliar Fertilizer Appetyzer $100-125 \mathrm{ml} / 100$ liters of water

Acadian Bio Tonic 75-100gm/100L Water

Grofalics growth regulator 2 tablets / 100 liters of water

The treatments for spraying these five chemicals, based on the instructions for their use, were divided into two phases:

1- Before flowering: The growth regulators included Horm and Fylloton on $5 / 5 / 2020$, then spraying was repeated on $17 / 5 / 2020$ and $26 / 5 / 2020$, i.e. three sprays, the period between one spray and another 10-12 days.

After flowering: It included spraying with growth regulators Grofalics, Appetyzer, Acadian on 1/6/2020 and then spraying again on 6/9/2020 and $6 / 20 / 2020$ at an average of 7-10 days between one spray and another. In front of the sixth treatment, it included the treatment with growth regulators Horm (before flowering) + Grofalics (beginning of flowering) and the dates specified for each of them in the instructions for use. As for the comparison treatment, it was sprayed with water only. For the purpose of determining the date of sampling, the weekly visits have continued and since 5/5/2020 (the date of the first spraying) in order to determine the date of the appearance of the infection on the tomato plants and thus the beginning of sampling, which was weekly. One sample included (30) leaves (10 leaves/repeat) Randomly taken from each treatment, sampling began with the first appearance of mites (14/7/2020) and continued until the end of the season. The samples were placed in sealed polyethylene bags and placed in a box containing a little ice. They were brought to the laboratory and placed in the refrigerator until the examination was conducted using Ordinary microscopy and recording and counting of motile individuals of $T$. urticae on two surfaces of tomato leaf. and registered.

The percentage of infected leaves was calculated using the equation:

$\%$ infection $=$ number of infected leaves $/$ number of leaves in the sample $\mathrm{x} 100$

The relative sensitivity of the cultivars was also calculated on the basis of $\%$ of infested leaves and the numerical density of mites as follows:

Relative sensitivity / number of individuals $=$ the average number of individuals in the dream / the lowest average number of individuals

For the purpose of studying the correlation between the number of mites and the prevailing temperatures and relative humidity during the season, the daily averages of temperature and relative humidity were obtained from the Meteorological Department in Nineveh Governorate, located in the Rashidiya area.

Determination of the leaves content of proteins, carbohydrates, phenols, flavonoids and alkaloids:

All experiments were carried out in the Entomology Research Laboratory / Plant Protection Department and the Central Laboratory of the College of Agriculture and Forestry during the year 2020. For the implementation of this study, samples were collected from the leaves of tomato plants of the six varieties 
used in the study separately, in addition to the comparison treatment. Unwanted impurities when left after brushing them on a smooth surface and under laboratory temperature to dry after that and using an electric mixer where they were ground and kept in powder of these leaves until the necessary analyzes were carried out, which included:

Protein determination: Protein determination was carried out according to the method (Ryan and Stephan, 2001). Included.

The stages of digestion and scaling and calculating the percentage of protein in the sample according to the following equation:

Crude protein percentage $=(6.25 \times 50 \times 14 \times$ volume $\mathrm{x}$ standard acid $) /(100 \mathrm{x}$ sample weight) x 100 .

\section{Carbohydrate estimation:}

Carbohydrates were estimated using Dubois method (1956), which included the preparation of a standard solution of glucose sugar by dissolving $0.1 \mathrm{~g}$ of glucose in 100 distilled $\mathrm{ml}$ to obtain a concentration of $1000 \mathrm{ppm}$ and then preparing a series of standard solutions 20,40, 50, 80 ppm

Reading by Spectrophotometer at a wavelength of $490 \mathrm{~nm}$ and then drawing the standard curve based on the results of reading the standard solutions.

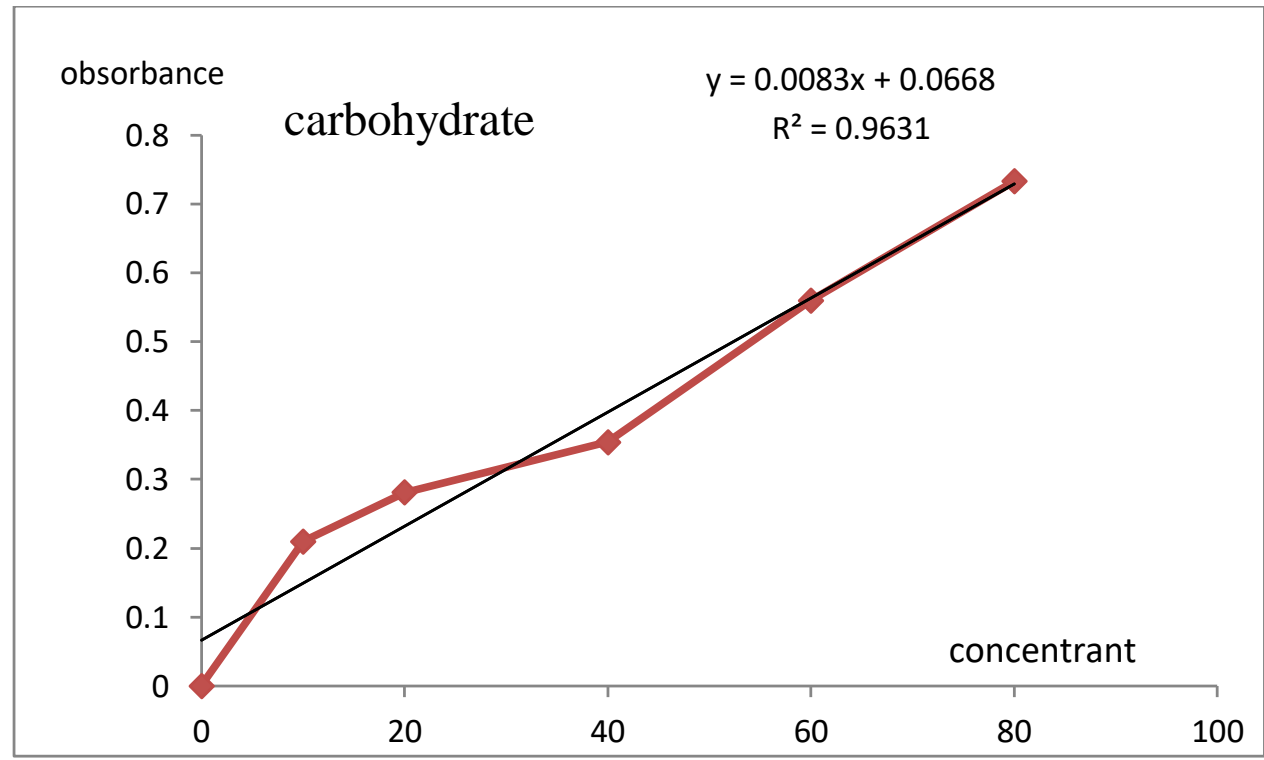

Figure(1)Standard Curve for Carbohydrates( Glucose).

\section{Estimation of phenols}

The total phenol content of leaves was estimated according to the method (Singleton and Rossi, 1965) and mentioned in Manal and Maria (2017).

It was based on the (Folin-ciocalteu) reagent, where the standard solution of galic acid was prepared by dissolving $0.008 \mathrm{~g}$ of Gallic acid (GAI) in 2 distilled $\mathrm{ml}$ to obtain a concentration of $4000 \mathrm{ppm}$, from which a series of standard solutions were prepared 62.5, 125, 250, 500, 1000 ppm Obtaining the ethanolic sample extract.

Measurement on a Spectrophotometer at $760 \mathrm{~nm}$ and then plotting the curve for concentrations in terms of absorbance. 


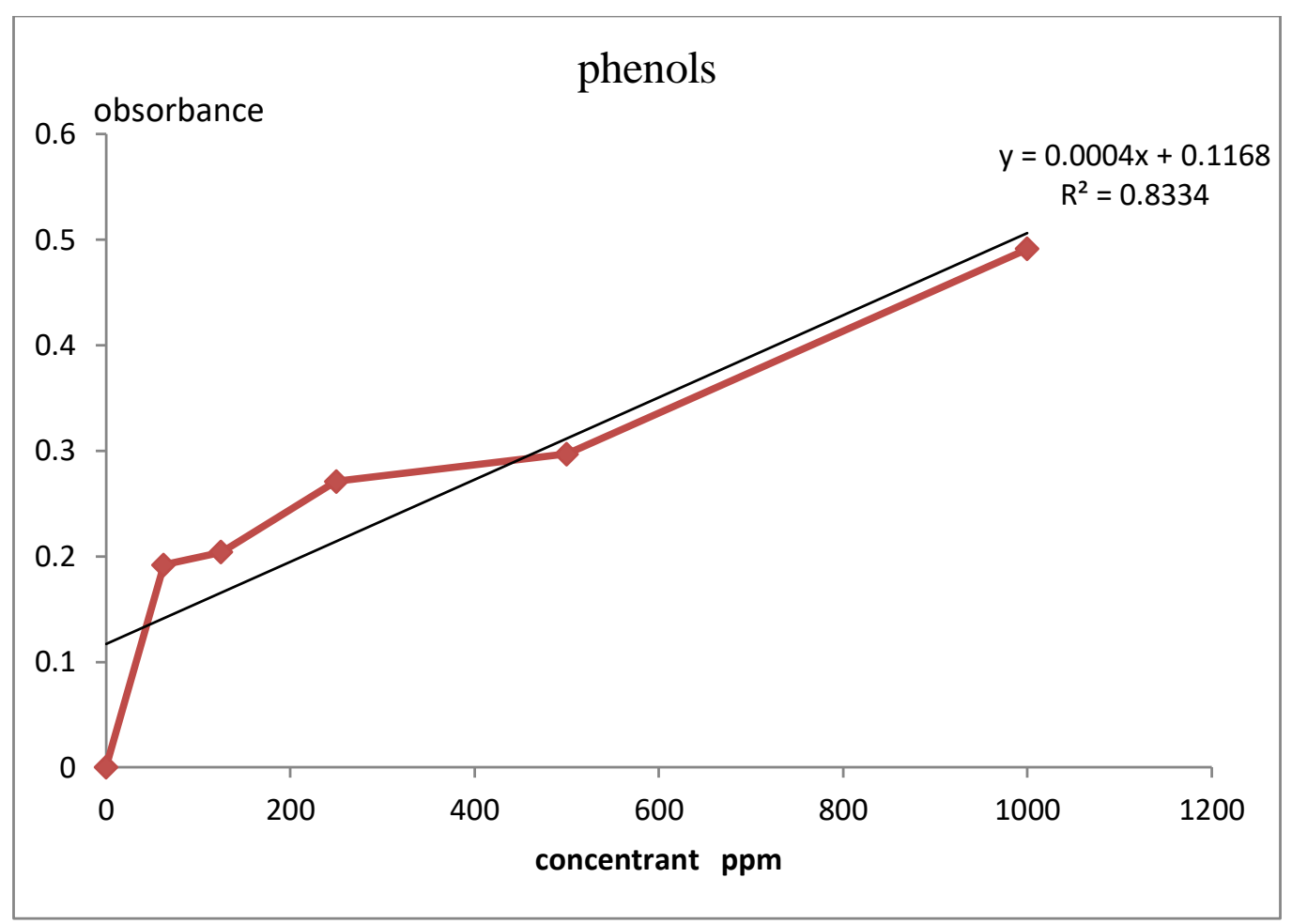

Figure:(2)Standard curve for phenols (Gallic acid).

\section{Estimation of flavonoids}

Then the determination of the flavonoids according to the method of woisky and salatino (1998) mentioned in Manal and Maria (2017) and the preparation of the standard solution of quercetin by dissolving $0.005 \mathrm{~g}$ of quercetin in $10 \mathrm{ml}$ of ethanol, we obtain a concentration of $500 \mathrm{ppm}$, and then we prepare a series of standard solutions 50, 100, 150, 200, 250, 300, 400, $500 \mathrm{ppm}$ and measured on a Spectrophotometer at $415 \mathrm{~nm}$ and then plotted the curve for concentrations in terms of absorbance

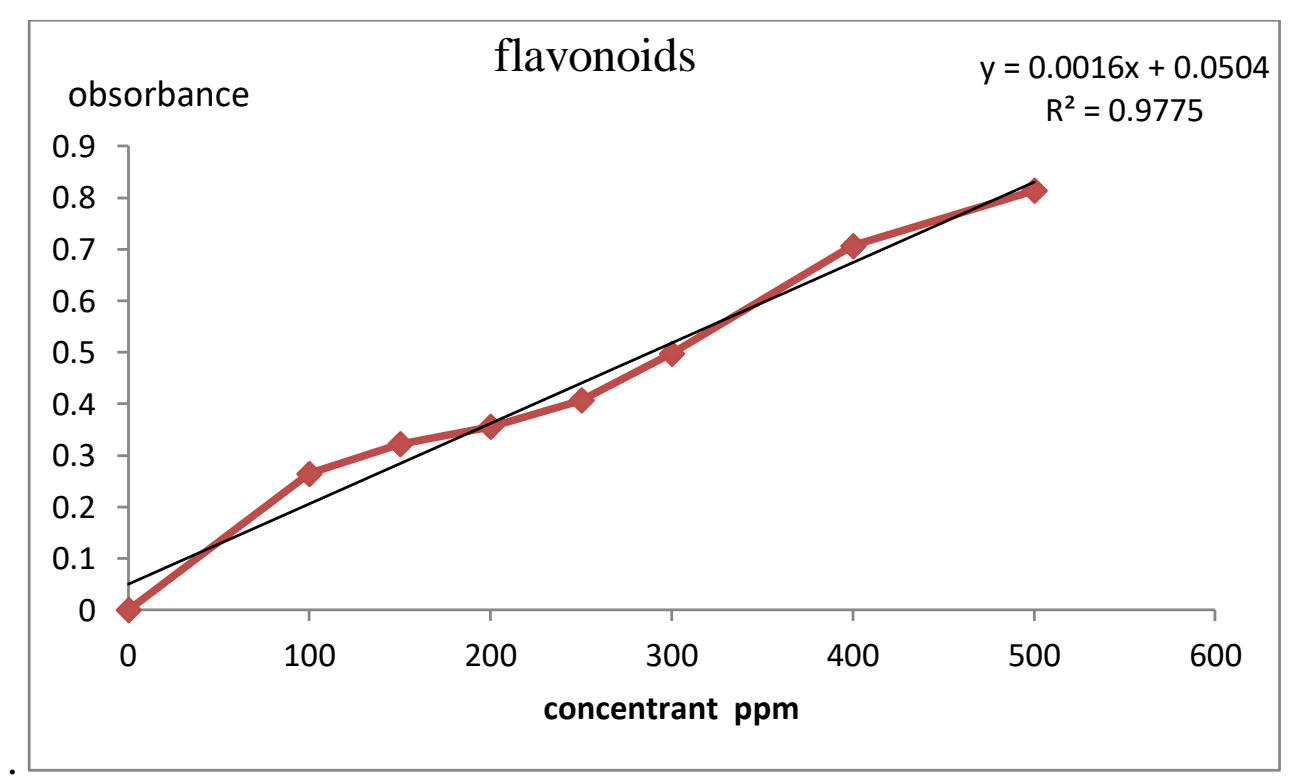

Figure(3):Standard curve for flavonoids (quercetin). 


\section{Estimation of Alkaloids:}

Alkaloids were estimated according to Mattilla (2007) method and mentioned in Al-Samarrai (2017).

Percentage of alkaloids $=($ alkaloid weight $) /($ sample weight $) \times 100$

\section{Statistical analysis}

The results of the field study were analyzed using the factorial random sector design and laboratory experiments using the complete random design, and the results were statistically analyzed using the calculator according to the SAS (Statistical Analysis System) Antar (2010) and compared the averages using the Duncan test.

\section{RESULTS AND DISCUSSION}

The effect of spraying with some agricultural chemicals on inducing resistance of tomato plants against $T$. urticae, including:

The effect of spraying with some agricultural chemicals on the seasonal activity of T. urticae

Table (1) shows that the number density of mites varied in their average numbers during the season, according to the chemical substance used, the treated variety, and the date of sampling, which ranged between $0-578.33$ individuals/10 leaves. The results of the statistical analysis indicate that there are significant differences in the averages of nipple numbers between different treatments compared to the control experiment, and that the lowest general average of these numbers was when treated with the growth regulator Horm 95.33 individuals/10 leaves, which was significantly different from all other spraying treatments, as well as with the comparison treatment with the exception of The two treatments of spraying with the growth regulators Fylloton (108.66 individuals) and Acadian (110.95 individuals), where the difference between them was not significant, while the treatment of spraying with the growth regulator Appetizer recorded the highest general average of mite count amounted to 142.24 individuals/10 leaves and a significant difference in all other spraying treatments except the treatment with Grofalix (130.06 individuals), where the difference between them was not significant. The results of the effect of the date of sampling indicate that the lowest general average of dream numbers was on 26/10 reaching 19.80 individuals/10 leaves which differed significantly from the rest of the dates except for the dates of taking readings $28 / 9,5 / 10,12 / 10,19 / 10$, which It reached 30.58 , 27.19, 22.69, 30.05 individuals/10 leaves, where the differences between them were not significant. As for the effect of the variety treated with agrochemicals, the results showed that the local variety was significantly superior in achieving the lowest average number of mites (104.09 individuals) compared to the GS variety (132.47 individuals), while it did not differ significantly in its preparation with the control experiment on the same variety (102.46 individuals). The results of the interaction effect between the cultivar and agricultural chemicals indicate that the lowest average number of mites was when treated with the growth regulator Horm for a local variety, which amounted to 83.00 individuals/10 leaves, with a significant difference from all other interaction treatments except for the treatment with Acadian (97.51 individuals) and fylloton (103.33 individuals), as well as the treatment of The comparison on the same variety 
(102.46 individuals), where the difference between them was not significant, and the highest average of these numbers was when treated with the growth regulator Appetyzer for the cultivar GS, where it reached 175.21 individuals/10 leaves and with a significant difference compared to the treatment of the control experiment as well as that treatment with other chemicals on the local tomato variety and GS From the above it is clear that spraying with the growth regulator Horm was the best in stimulating and inducing the resistance of tomato plants, based on the numerical density criterion, as it gave the lowest average number of mites during the season, followed in this field by the growth regulators, fylloton and Acadian, and that the local variety was the most responsive to all these treatments in achieving less Average number of mites compared to the GS variety.

This may agree with what Ament et al., (2004) mentioned about Jasmonic acid and its role in inducing direct and indirect plant defenses against the two-spot spider on tomato plants, where it was found that this acid is necessary to induce the enzymatic conversion of salicy acid (SA) to methyl transfer, and thus the necessity of Jasmonic acid (SA) to methyl transfer. To establish the indirect defensive response induced against the spider on the tomato. As well as what Thakur and Sohal (2013) mentioned in their review of the role of chemical stimuli in supporting plant resistance against disease infections, and they pointed out the most important of these stimuli, which had previously been tested for their effect in stimulating plant defenses, including salicylic acid, methyl salic acid, ben Zoic acid, Chitosam, which affect Production of phenolic compounds and activation of various defense enzymes in plants. In a study by Saad (2020) on the effect of treating squash plants with cytoxin on whitefly and two-spot mite infection, the results showed that plants treated with a concentration of $25 \mathrm{ppm}$ had a low infection with both compared to untreated plants, and the results also showed that treating squash plants with a concentration of $25 \mathrm{ppm} 25 \mathrm{ppm}$ improved the phenotypic and internal components of the plant compared to untreated plants, while high concentration $45 \mathrm{ppm}$ had a bad effect on the phenotypic and internal components of these plants compared to the untreated.

Effect of some agricultural chemicals on the percentage of infected leaves and the number of two-spot mites during the season 2019-2020

Table (2 ) shows that the average percentage of leaves infected with mites on tomato cultivar GS and treated with chemicals Fylloton, Horm, Appetyzer, Grofalex, Acadian, Grofalex + Horm amounted to 66.8, 67.92, 75.87, 67.16, $69.71,73,28 \%$, respectively, compared with the experiment. control, which amounted to $63.5 \%$

The results of the statistical analysis showed that there were significant differences in the results of the effects of spraying with chemicals compared to the untreated control experiment, and that the lowest average $\%$ of infected leaves for the spraying treatments was recorded for the spraying treatment with fylloton $66.88 \%$, followed by the two treatments of spraying with Horm $(67.92 \%)$ and Grofalex $(67.16 \%)$, where no The difference between them was significant, while the percentage of treatments in $\%$ of the affected leaves were ascending as follows: Acadian, Grofalex + Horm and Appetyzer, which amounted to $69.71,73.28,75.87 \%$, respectively. 
From the foregoing and based on the $\%$ criterion for infected leaves, it turns out that there was no effect of the aforementioned treatments in inducing these plants of the tomato GS variety to be infected with mites, rather the opposite, as the treatment with these chemicals led to a significant increase in the sensitivity of these plants to infection by increasing \% of infected leaves and thus apparently The role of these transactions was to increase the attraction of mite individuals, whether for feeding or laying eggs for the leaves treated with these chemicals. As for the average number of mites on the leaves of the GS variety and treated with the aforementioned chemicals, it reached 114.38, 107.67, 175.21, 134.38, 147.54 and 130.36 individuals/10 sheets, respectively, compared to the control experiment, which amounted to 127.77 individuals/10 sheets. The results of the statistical analysis showed that the lowest average number of mites recorded was for the treatment of spraying with the growth regulator Horm (107.67 individuals / 10 leaves) and with a significant difference compared to all treatments, including the comparison treatment, followed by the treatment with growth regulators Fylloton (114.38 individuals) and Grovalex (124.38 / individual) where it was The differences between them are significant, while the highest average number of mites was recorded when treated with the epitaxic growth regulator (175.21 individuals) with a significant difference compared to all treatments, including the comparison treatment. From the above it is clear that there is a discrepancy in the results of the aforementioned spraying treatments compared to the control treatment (non-spraying) with regard to reducing or increasing the number of mites on the leaves of infected plants of the GS variety, and that the treatment with growth regulators, Fylloton Horm and Grofalex led to a reduction in the averages of these numbers compared to the control treatment and thus had Dura-positive in the so-called induction of resistance against infection, while the role of the rest of the treatments (Appetyzer,Acadian and Grofalex + Horm) was negative in this field, as these treatments increased the sensitivity of these plants to infection. As for the effect of these spraying treatments on the average $\%$ of infected leaves and the number of mite individuals on the local variety, the results mentioned in Table (2) also indicated a variation in the values of these averages according to the type of treatment, as they were distributed according to the $\%$ criterion for infected leaves between a significant decrease of $\%$ for infected leaves Compared with the control experiment and thus an indicator of resistance induction, which was recorded for the two treatments of spraying with Horm (67.65\%) and Eppetizer (68.43\%), where the differences between them were not significant and differed significantly from the treatment of the control experiment $(75.10 \%)$, while the rest of the treatments led to an increase in $\%$ of the affected leaves with a significant difference from the comparison treatment and that these treatments were arranged ascendingly in the values of these averages as follows Fylloton, Grofalex, Acadian, Grofalex + Horm, which amounted to 78.42, 78.67, 83.83, $85.36 \%$, respectively, as the statistical analysis showed significant differences between them on the one hand, as well as between them all compared with the control experiment. As for the effect of spraying treatments on the average number of mites on the leaves of infected plants of the local variety, the results 
of the statistical analysis indicated the significant effect of these treatments in reducing or increasing the number of mites compared to the untreated control experiment, and that the lowest average of these numbers was for the two spraying treatments with Horm (83.00 individuals) and Grovalx (97.51 individuals) with a significant difference from the comparison treatment (102.46 individuals), which indicates its role in inducing the comparison of these plants against mites infection and that the highest average number of mites has been recorded for the treatment Grofalex + Horm (120.44 individuals), followed by the treatment with Bad Acadian (112.59 individuals). With a significant difference compared to the treatment of the control experiment. The results of the correlation study indicated that there was an insignificant negative correlation between the two parameters of the percentage of infected leaves and the number of mites treated with the aforementioned agricultural chemicals, which amounted to $(-0.036)$.

In a study by Leroy et al. (2019) on silicon, plant natural defenses against insects, and the effect of volatile organic compounds and its effect on multiple herbivores, there is general agreement about the ability of plants fertilized with silicon to better resist insect feeding. Recent studies also indicate that silicon paves biochemical defense pathways. in different plant families. 
Table (1): Effect of spraying with some agricultural chemicals on the seasonal activity of the two-spot mite Tetranychus urticae

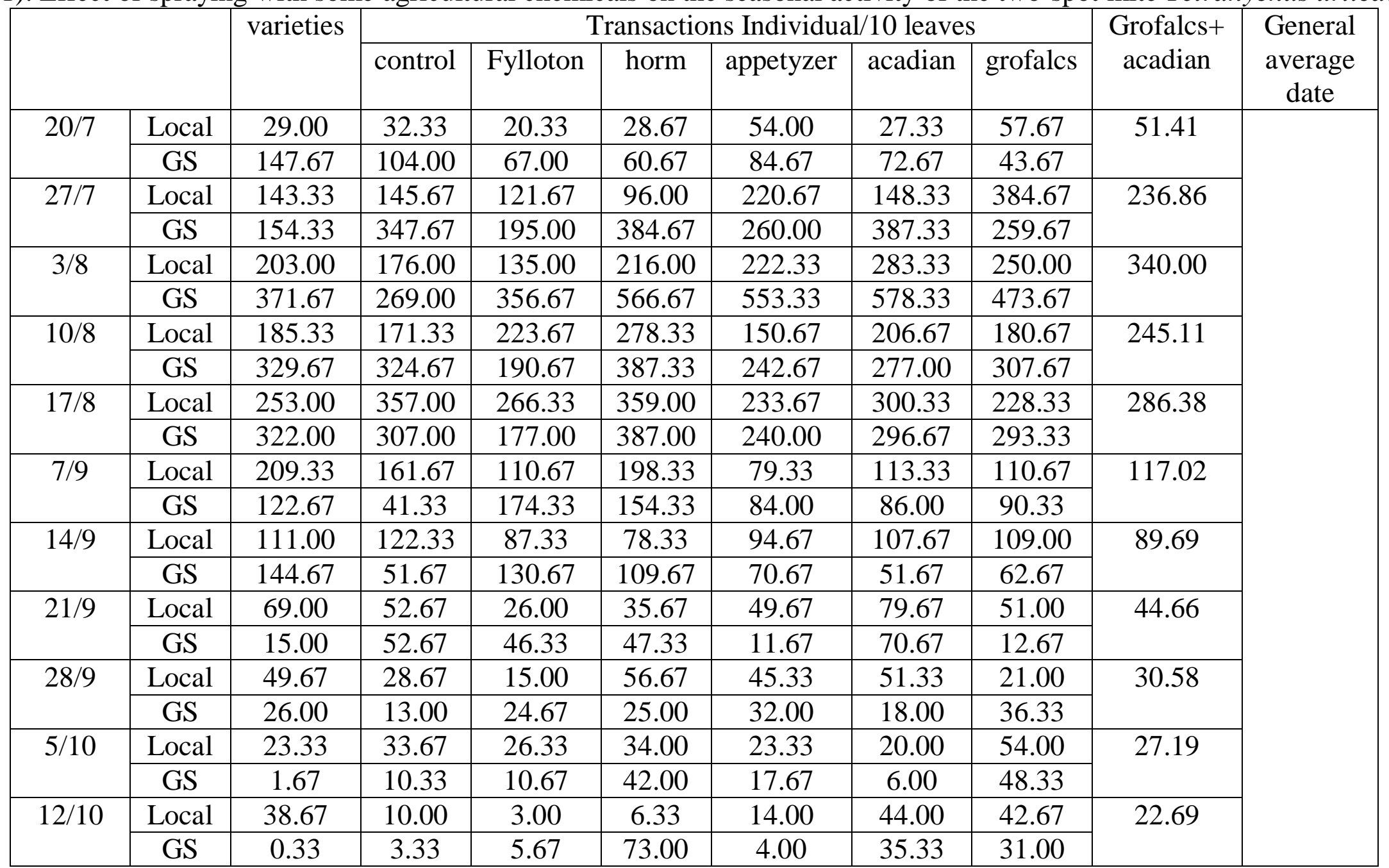


Mesopotamia Journal of Agriculture, Vol. 49, No. 4, 2021 (59-76)

\begin{tabular}{|c|c|c|c|c|c|c|c|c|c|}
\hline \multirow[t]{2}{*}{$19 / 10$} & Local & 12.00 & 33.00 & 24.33 & 33.33 & 41.00 & 44.67 & 47.33 & \multirow[t]{2}{*}{30.05} \\
\hline & GS & 18.67 & 36.67 & 21.00 & 25.33 & 11.67 & 24.33 & 18.00 & \\
\hline \multirow[t]{2}{*}{$26 / 10$} & Local & 5.33 & 5.33 & 19.00 & 0.00 & 39.00 & 37.33 & 28.67 & \multirow[t]{2}{*}{19.80} \\
\hline & GS & 7.67 & 25.67 & 0.00 & 23.67 & 4.67 & 23.00 & 17.33 & \\
\hline \multicolumn{2}{|c|}{$\begin{array}{c}\text { General average } \\
\text { chemicals }\end{array}$} & 115.12 & 108.86 & 93.33 & 142.24 & 110.95 & 130.06 & 125.40 & \\
\hline \multirow{2}{*}{$\begin{array}{c}\text { interacti } \\
\text { on } \\
\text { variety } \\
\text { chemic } \\
\text { als }\end{array}$} & Local & 102.46 & 103.33 & 83.00 & 109.28 & 97.51 & 112.59 & 120.44 & 104.09 \\
\hline & GS & 127.77 & 114.38 & 107.67 & 175.21 & 124.38 & 147.54 & 130.36 & 132.47 \\
\hline \multirow{2}{*}{\multicolumn{2}{|c|}{$\begin{array}{c}\text { General average } \\
\text { variety }\end{array}$}} & Local & \multirow{2}{*}{\multicolumn{7}{|c|}{$\begin{array}{l}103.93 \\
133.78\end{array}$}} \\
\hline & & GS & & & & & & & \\
\hline
\end{tabular}

LSD value at $5 \%$ for the overlap between sampling date, variety and chemicals 84.33

LSD value at the $5 \%$ level for the general average of the date 22.54

LSD value at 5\% level for interaction between variety and chemicals 23.39

LSD value at $5 \%$ for the overall median chemical 16.54

The value of the LSD at the level of 5\% for the general average of the varieties 8.84 
Table (2): The effect of spraying with some agricultural chemicals on the general average of the percentage of infected leaves and the number of mites during the season 2019-2020

\begin{tabular}{|c|c|c|c|c|c|}
\hline \multirow[t]{2}{*}{ varieties } & \multirow[t]{2}{*}{ chemicals } & \multicolumn{2}{|c|}{$\%$ of infected leaves } & \multicolumn{2}{|c|}{$\begin{array}{l}\text { The general average of the } \\
\text { number of mites individual / } 10 \\
\text { leaves }\end{array}$} \\
\hline & & Term & $\begin{array}{c}\text { overall } \\
\text { average }\end{array}$ & Term & $\begin{array}{c}\text { overall } \\
\text { average }\end{array}$ \\
\hline \multirow[t]{7}{*}{ GS } & control & $3,3-100$ & $63,05 \mathrm{i}$ & $0,33-371,67$ & $127,77 \mathrm{~d}$ \\
\hline & fylloton & $26,6-100$ & $66,88 \mathrm{~h}$ & 3,33---324,67 & $114,38 \mathrm{~g}$ \\
\hline & horm & $0-100$ & $67,92 \mathrm{gh}$ & 0 ------356,67 & $107,67 \mathrm{j}$ \\
\hline & appetyzer & $46,6-100$ & $75,87 \mathrm{~d}$ & 0 ------566,67 & $175,21 \mathrm{a}$ \\
\hline & grofalics & $20-100$ & $67,16 \mathrm{~h}$ & 4,0-----553,33 & $124,38 \mathrm{e}$ \\
\hline & acadian & $23,3-100$ & $69,71 \mathrm{f}$ & $6,0---578,33$ & $147,54 b$ \\
\hline & $\begin{array}{c}\text { Grofalics+ } \\
\text { horm }\end{array}$ & $40-100$ & $73,21 \mathrm{e}$ & $12,67-437.67$ & $130,46 \mathrm{c}$ \\
\hline \multirow[t]{7}{*}{ Local } & control & $23,3-100$ & $75,10 \mathrm{~d}$ & $5,33---253,0$ & $102,46 \mathrm{k}$ \\
\hline & fylloton & $23,3-100$ & $78,42 \mathrm{c}$ & $10,0---357,0$ & $103,33 \mathrm{k}$ \\
\hline & horm & $16,6-100$ & $67,65 \mathrm{gh}$ & $3,0----266,33$ & $83,00 \mathrm{~m}$ \\
\hline & appetyzer & $0-100$ & $68,43 \mathrm{~g}$ & $6,33-359,0$ & $109,28 \mathrm{i}$ \\
\hline & grofalics & $43,3-100$ & $78,67 \mathrm{c}$ & $14,0-233,67$ & $97,51 \mathrm{i}$ \\
\hline & acadian & $36,6-100$ & $83,83 \mathrm{~b}$ & $20,0---300,00$ & $112,59 \mathrm{~h}$ \\
\hline & $\begin{array}{c}\begin{array}{c}\text { Grofalics+ } \\
\text { horm }\end{array} \\
\end{array}$ & $46,6-100$ & $85,36 a$ & $21,00-384,67$ & $120,44 f$ \\
\hline
\end{tabular}

The averages with dissimilar letters in the same sector indicate the presence of significant differences at the 5\% probability level according to the Duncan test.

\section{Effect of spraying with some agricultural chemicals on the content of essential nutrients in tomato leaves.}

Table (3) shows that there is a discrepancy in the content of tomato leaves of proteins, carbohydrates, phenols, flavonoids and alkaloids, according to the type of treatment and the treated variety (GS, local) as well as the untreated comparison treatment and that the highest content of proteins for leaves of class GS was for the treatment of Grofalex + Horm (5.63 g / $100 \mathrm{~g})$, which was significantly superior to all other treatments, including the control treatment $(4.71 \mathrm{~g} / 100 \mathrm{~g})$. All other treatments, including the comparison treatment, except for spray and Gerfalex (4.90) and Grofalex + Hrum (5.63 g), where the differences between them were not significant

It also appears from the same table that the effect of these treatments on the protein content of the leaves differed according to the treated variety and that the highest content recorded on the local variety was for Acadian $(5.87 \mathrm{~g})$ and Fylloton $(5.51 \mathrm{~g})$, where the differences were not significant, while they differed significantly from all treatments. The other, including the unconfused comparison treatment, while the rest of the treatments graded in descending order in their content of proteins as follows: Grofalex $(4.90 \mathrm{~g})$ Grofalex + Horm $(4.90 \mathrm{~g})$, Appetizer (4.70 g) Horm (4.77) which did not differ significantly while 
and also with the treatment Comparison $(5.01 \mathrm{~g})$. As for the carbohydrate content of GS-class tomato leaves, the highest value recorded was for the two treatments Eppetizer (0.86 g / $100 \mathrm{~g})$ and Fyllotone $(0.80 \mathrm{~g} / 100 \mathrm{~g})$, where the differences between them were not significant, while they differed significantly from all other treatments, including the control treatment $(0.56 \mathrm{~g})$. ) As for the lowest carbohydrate content, it was for spraying with Horm $(0.54 \mathrm{~g})$, which did not differ significantly from the rest of the other treatments, including the comparison treatment, except for the treatment with Grofalex (0.68 g), Appetyzer and Fylloton, where the differences between them were not significant. As for the local cultivar, the treatment with Fylloton was significantly superior in achieving the highest carbohydrate content of 0.69 $\mathrm{g} / 100 \mathrm{~g}$ compared with all other treatments, including the control treatment $(0.60$ $\mathrm{g}$ ), while the Grofalex + Horm treatment gave the lowest carbohydrate value of $0.33 \mathrm{~g}$ with a significant difference from its counterparts in other transactions.

As for the phenols content of GS cultivar leaves, the results showed that the highest phenol content was recorded for the two spraying treatments with Fylloton $(15.58 \mathrm{mg} / \mathrm{g})$ and Acadian $(15.83 \mathrm{mg} / \mathrm{g})$, where they did not differ significantly, while they differed significantly from all other treatments, including the comparison treatment $(10.83 \mathrm{mg})$, and the lowest content of phenols was for the spray treatment with Appetyzer $(10.58 \mathrm{mg})$, which did not differ significantly from the control treatment $(10.83 \mathrm{mg})$ and Grofalex + Horm (11.08 mg). As for the local variety, all spraying treatments led to a significant decrease in the leaves' content of phenols compared to the comparison equation $(12.08 \mathrm{mg})$, except for the treatment with Fylloton $(11.58 \mathrm{mg})$, where the difference between them was not significant and that the lowest value of phenols was when the treatment was Acadian, which amounted to 6.08 The values of flavonoids for tomato leaves of the two cultivars differed according to the spraying treatment, and the highest content of flavonoids was obtained from the two spraying treatments with Fylloton $(5.81 \mathrm{mg})$ and Grofalex $(5.93 \mathrm{mg})$ for the GS variety, with a significant difference from all other treatments, including the treatment The comparison $(4.06 \mathrm{mg})$, while the treatment with Appetizer gave the lowest content of flavonoids, which was $2.62 \mathrm{mg}$, with a significant difference from all other treatments, including the comparison factor. As for the local variety, as is the case with phenols, all spraying treatments led to a significant decrease in the leaf content of flavonoids compared to the control treatment $(4.56 \mathrm{mg})$, and the lowest value of flavonoids was when spraying with Grofalex + Horm $(2.85 \mathrm{mg})$, which did not differ significantly. From the rest of the spray treatments, except for the treatment with Appetyzer $(3.68 \mathrm{mg})$, where the difference between them was significant. As for the content of GS of tomato leaves of alkaloids, the results showed that the highest content in it was in the two treatments of Appetyzer (2.96 g) and Acadian (2.74 g), where the difference between them was not significant, while they differed significantly with all other treatments, including the control treatment $(1.74 \mathrm{~g})$. And the lowest value of alkaloids was when treated with Fylloton $(1.72 \mathrm{~g})$, which did not differ significantly in its value with the untreated comparison treatment. While the effect of these treatments differed when the leaves were of the local variety, and 
the highest value of alkaloids was recorded when treated with Fylloton (2.48 g), followed by spraying with Grofalex + Horm (2.44 g), Grofalex (2.40) and Acadian $(2.26 \mathrm{~g})$, where no The difference between them was significant, while they differed significantly from the rest of the treatments, including the comparison treatment $(1.94 \mathrm{~g})$.

As for the effect of the general average of these treatments in tomato GS and local cultivars, the statistical analysis proved the superiority of GS cultivar leaves significantly in giving the highest content of carbohydrates, flavonoids and flavonoids, reaching $0.67 \mathrm{gm}, 12.91 \mathrm{mg}, 4.35 \mathrm{mg}$ respectively compared with the local cultivar. While the local cultivar was significantly superior in the protein content of leaves only (5.12 g) compared with the GS cultivar, while the spraying treatments had no effect on the general average of alkaloids, which amounted to 2.30 and 2.28 gm on the tomato cultivars GS and local respectively. The foregoing is in general agreement with many previous studies in this field, which showed that the supply of plants with certain nutrients or growth regulators led to an increase or decrease in some of the basic nutrients included in the composition of the different parts of the plant, especially the leaves and fruits, including a study by Besford (1975) on the effect of Nutrition with potassium in the concentration of leaf protein and in the growth of tomato plants, where the concentration of protein in the plant increased significantly with a decrease in the plant's supply of potassium compared to the natural or recommended concentration of potassium added to these plants. In a study by Stewart et al., (2001) on the effect of nitrogen and phosphorous deficiency on the accumulation of flavonoids in plant tissues, the results showed a significant increase in the accumulation of flavonol in mature leaves in response to nitrogen pressure, while phosphorous deficiency did not affect the increase or decrease of flavonol accumulation in the leaves as the study showed Nutrients may be used to treat flavonol content in vegetable tissues, but they cannot be used to increase flavonol content in tomato fruits.

In a study by Olaiya and Adigun (2010) on the chemical manipulation of growing tomatoes and the biochemical effects associated with flavonoids, lycopene and mineral contents, the results showed that the content of flavonoids and lycopene increased significantly in tomato plants treated with IAA, IBA and NAA compared to the control treatment. 
Table (3) Effect of spraying with some agricultural chemicals on the content of essential nutrients in tomato leaves

\begin{tabular}{|c|c|c|c|c|c|c|}
\hline varieties & & \multicolumn{5}{|c|}{ Leaves content } \\
\cline { 2 - 7 } & treatments & $\begin{array}{c}\text { Proteins } \\
\text { g/100g }\end{array}$ & $\begin{array}{c}\text { Carbohydr } \\
\text { ates g/100g }\end{array}$ & $\begin{array}{c}\text { phenols } \\
\mathrm{mg} / \mathrm{g}\end{array}$ & $\begin{array}{c}\text { Flavonoi } \\
\text { ds mg/g }\end{array}$ & $\begin{array}{c}\text { Alkaloid } \\
\mathrm{sg} / 100 \mathrm{~g}\end{array}$ \\
\hline \multirow{4}{*}{ GS } & control & $4,71 \mathrm{~b}-\mathrm{e}$ & $0,56 \mathrm{~d}-\mathrm{e}$ & $10,83 \mathrm{e}$ & $4,06 \mathrm{c}$ & $1,74 \mathrm{e}$ \\
\cline { 2 - 7 } & fylloton & $4,65 \mathrm{~b}-\mathrm{e}$ & $0,80 \mathrm{a}$ & $15,58 \mathrm{a}$ & $5,81 \mathrm{a}$ & $1,72 \mathrm{e}$ \\
\cline { 2 - 7 } & horm & $4,40 \mathrm{~d}-\mathrm{e}$ & $0,54 \mathrm{~d}-\mathrm{e}$ & $11,58 \mathrm{c}-\mathrm{d}$ & $3,50 \mathrm{~d}-\mathrm{e}$ & $1,98 \mathrm{a}$ \\
\cline { 2 - 7 } & appetyzer & $4,28 \mathrm{e}$ & $0,86 \mathrm{a}$ & $10,58 \mathrm{e}$ & $2,62 \mathrm{c}$ & $2,96 \mathrm{a}$ \\
\cline { 2 - 7 } & grofalics & $4,90 \mathrm{~b}-\mathrm{c}$ & $0,68 \mathrm{~b}-\mathrm{c}$ & $12,83 \mathrm{~b}$ & $5,93 \mathrm{a}$ & $2,22 \mathrm{~b}-\mathrm{c}$ \\
\cline { 2 - 7 } & acadian & $4,53 \mathrm{c}-\mathrm{e}$ & $0,59 \mathrm{~d}$ & $15,83 \mathrm{a}$ & $4,18 \mathrm{c}$ & $2,74 \mathrm{a}$ \\
\cline { 2 - 7 } & Grofalics+horm & $5,63 \mathrm{a}$ & $0,56 \mathrm{~d}-\mathrm{e}$ & $11,08 \mathrm{~d}-\mathrm{e}$ & $4,06 \mathrm{c}$ & $2,20 \mathrm{~b}-\mathrm{d}$ \\
\hline Local & control & $5,01 \mathrm{~b}$ & $0,60 \mathrm{c}-\mathrm{e}$ & $12,08 \mathrm{c}$ & $4,56 \mathrm{~b}$ & $1,94 \mathrm{~d}-\mathrm{e}$ \\
\cline { 2 - 7 } & fylloton & $5,51 \mathrm{a}$ & $0,69 \mathrm{~b}$ & $11,58 \mathrm{c}-\mathrm{d}$ & $2,93 \mathrm{~g}-\mathrm{h}$ & $2,48 \mathrm{~b}$ \\
\cline { 2 - 7 } & horm & $4,77 \mathrm{c}$ & $0,53 \mathrm{~d}-\mathrm{e}$ & $7,33 \mathrm{~g}$ & $3,31 \mathrm{e}-\mathrm{f}$ & $2,02 \mathrm{c}-\mathrm{d}$ \\
\cline { 2 - 7 } & appetyzer & $4,77 \mathrm{~b}-\mathrm{d}$ & $0,54 \mathrm{~d}-\mathrm{e}$ & $6,83 \mathrm{~g}$ & $3,68 \mathrm{~d}$ & $2,08 \mathrm{c}-\mathrm{d}$ \\
\cline { 2 - 7 } & grofalics & $4,90 \mathrm{~b}-\mathrm{c}$ & $0,50 \mathrm{c}$ & $10,83 \mathrm{e}$ & $3,16 \mathrm{e}-\mathrm{g}$ & $2,40 \mathrm{~b}$ \\
\cline { 2 - 7 } & acadian & $5,87 \mathrm{a}$ & $0,60 \mathrm{c}-\mathrm{d}$ & $6,08 \mathrm{~h}$ & $2,87 \mathrm{~g}-\mathrm{h}$ & $2,26 \mathrm{~b}-\mathrm{c}$ \\
\cline { 2 - 7 } & Grofalics+ horm & $4,90 \mathrm{~b}-\mathrm{c}$ & $0,33 \mathrm{f}$ & $8,83 \mathrm{f}$ & $2,85 \mathrm{~g}-\mathrm{h}$ & $2,44 \mathrm{~b}$ \\
\hline
\end{tabular}

The averages with dissimilar letters in the same sector indicate the presence of significant differences at the 5\% probability level according to the Duncan test.

تأثير الرش ببعض الكيميائيات الزراعية في استحثاث مقاومة نباتات الطماطة ضد الاصابة بالحلم ذي

Tetranychus urticae Koch البقعتين

$$
\begin{aligned}
& \text { عبد العزيز علوان مصطفى } 1 \text { نبيل مصطفى الملاح² } \\
& \text { 1 كلية الزراعة جامعة تلعفر } \\
& \text { 2قسم وقاية النبات - كلية الزراعة والغابات - جامعة الموصل التراعل }
\end{aligned}
$$

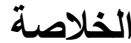

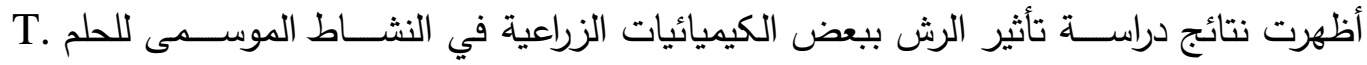
خurticae

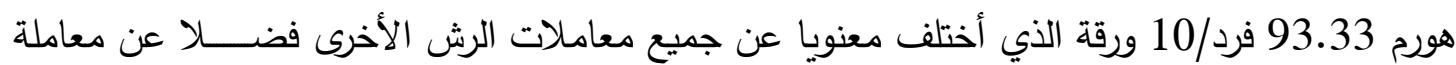

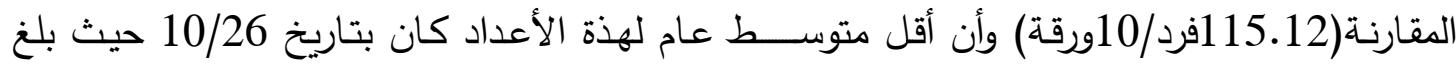

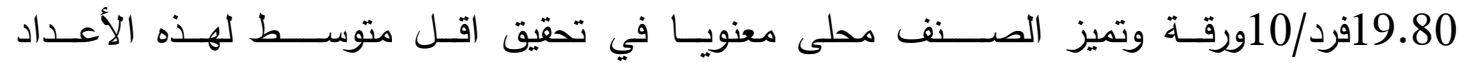

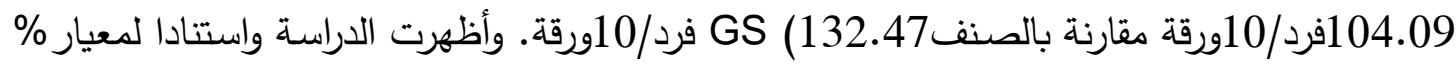

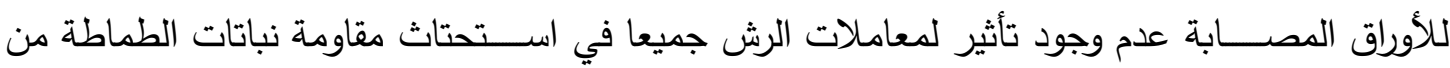

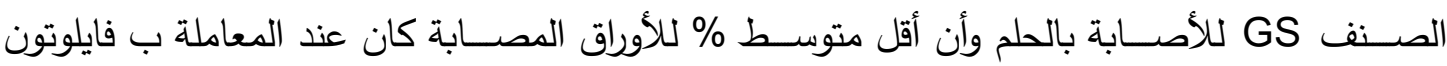


(66.88\%)مقارنـة مع التجربـة الضـــــابطة والتتى بلغت 63.05\% في حين أظهرت نتائج التحليل الأحصائى والخاصـة بمعيار الكثافة العددية للحلم أن أقل متوسط لأعداد الحلم كان عند المعاملة بمنظم النموهورم(107.67فرد/10ورقة)وبفـارق معنوى مقارنــة بمعاملات الرش الأخرى فضــــلا عن معـاملة المقارنة (127.77فرد)حيث تباينت معاملات الرش فيما بينهما فيما يخص خفض او زيادة أعداد الحلم على أوراق الطماطة من الصنف GS وان المعاملة ب هورم ،فايلوتون وجروفالكس ادت الى خفض في

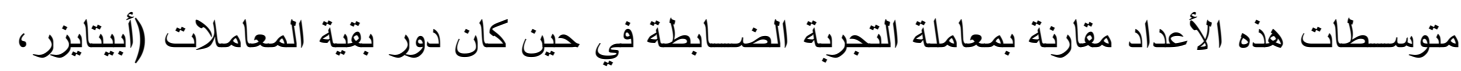
أكاديان، جروفالكس +هورم) سلبيا في هذا المجال حيث ادت الى زيادة حساسية هذه النباتات للأصابة. وتقوق الصــنف GS معنويا فى اعطاء اعلى محتوى من الكاربوهيدرات والفينولات والفلافونويدات حيث هوهيث

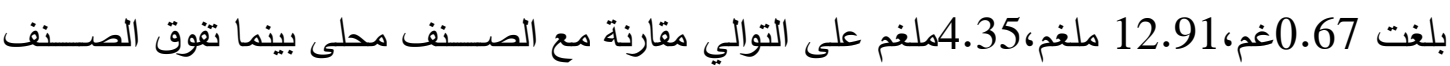

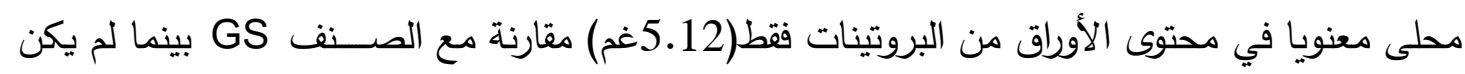

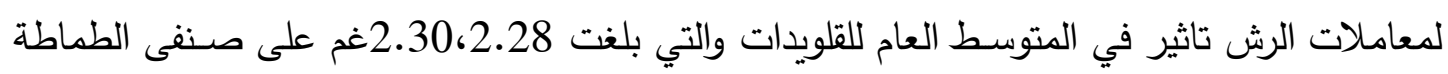
GS

الكلمات المفتاحية: الكيميائيات الزراعية ، الصنف محلي، الكثافة العددية.

\section{REFERENCES}

Adkisson,P.L.(2006).Resistant varieties in pest management system. Department of Entomology. Texas University. Technical report. P233259.

AL-Samarrai,N.A.H. (2017)Estimate of the flavonoids in the leaves of Bay laurel studying their-Bio-activity.Tikrit Journal of pure sciences.

Ament, K., Kant, M. R., Sabelis, M. W., Haring, M. A., \& Schuurink, R. C. (2004). Jasmonic acid is a key regulator of spider mite-induced volatile terpenoid and methyl salicylate emission in tomato. Plant physiology, 135(4): 2025-2037.

Antar, salem. Hammadi. (2010). Statistical Analyses in scientific Research on the SAS program, University of Mosul, College of Agricultural and Forestry, Dar al-Kutub and publishing p192.

Besford,R.T.(1975).Effect of potassium nutrition on leaf protein concentrations and growth of young tomato plants. plant and soil 42(2):441-451.

DUBOIS, M. K., GILLES, K. A., HAMILTON, J. K., REBERS, P. A., Smith F. (1956). Colorimetric method for determination of sugars and related substances. Analytical chemistry (3) 28:350-356.

Euro stat.(2019).European commission(http;//ec.europa.eu/Eurostat.

FAO STAT.(2019).Food and Agriculture Organization of The United Nations(http://fao.org/faostat/en).

George, A.A.T.(2011).Tropical vegetable production.UK, The MPG Books Group. p235.

Gimens, F.R. ,.Erb, W.A., Bishop, B.L. and Scheerens J.C. .(1994).Host plant relationships between the two spotted spider mite(Acarina: 
Tetranychidae) and strawberry cultivars with differing levels of resistance. Journal of Economic Entomology(USA),87(1):168-175.

Hanley, M. E., Lamont, B. B., Fairbanks, M. M., \& Rafferty, C. M. (2007). Plant structural traits and their role in anti-herbivore defence. Perspectives in Plant Ecology, Evolution and Systematics, 8(4), 157-178.

Keskin,N., \& Kumral, M.A.(2015).Screening tomato varietal resistance against the two spotted spider mite Tetranychus urticae Koch. International Journal of acarology.41(4):300-309.

Leroy, N., de Tombeur, F., Walgraffe, Y., Cornélis, J. T., \& Verheggen, F. J. (2019). Silicon and plant natural defenses against insect pests: Impact on plant volatile organic compounds and cascade effects on multitrophic interactions. Plants, 8(11), 1-11.

Litskas,V., Migeon, A., Navajas,M., Tixier, M.S., \& Stavrinides, M.C.(2019).Impact of climate change on tomato, anotorious pest and its natural enemy: small scale agriculture at higher risk. environmental. research. lettters 14.1-10.

Luczynski,A.,Isman, M.B., Raworth, D.A., and. Chan, C.K.(1990).Chemical and morphological factors of resistance against the two spotted spider mite in beach strawberry: Journal of Economic Entomology:83(2):564569.

Manal, H., Maria, D. (2017). Contribution to the anatomical study, chemical content and effectiveness of Al-Arfaj extract. Master's thesis of the College of Science/Department of Biology/University of Al-Shahid Khamma, Hadhra-Wadi p 50.

Mattila, P., Hellstron, J.(2009).phenolic acids in potatoes vegetable and some of their products. journal. food composition. Analysis.20:152-160.

Modal,M. N.(2006) Biology and fecundity of the two-spotted spider mites Tetranychus urticae Koch under laboratory condition. Journal of life earth science., 1(2):43-47.

Olaiya, C.O., and Adigun, A.A. (2010).Chemical manipulation of tomato growth and associated biochemical implications on flavonoid, lycopene and mineral contents. African Journal of plant Scince.4(6).167-171.

Ryan,j., \& Stephan, G. (2001) Soil and Plant Analysis Laboratory Manual ICARDA Aleppo, Syria. P 173.

Saad,H.M.(2020).Effect of treated squash plant by Cytokinin hormone(CKs) on the infestation by Bemisia tabaci and Tetranychus urticae.Egyption Academic Journal of Biological and sciences., 13 (1): 33-40.

Singleton, V.L. ,and Rossi ,J.A.(1965)colorimetry of total phenolics with phosphomolybdic - phpsphotungstic acid reagents. American Journal of Enology and viticulture. 16(3):144-158.

Sohal, B.S., and Thakur, M, (2013).Role of Elicitors in inducing Resistance in plants against pathogen Infection: A review. ISRN Biochemistry.1-10.

Stewart, A. J., Chapman, W., Jenkins, G. I., Graham, I., Martin, T., \& Crozier, A. (2001). The effect of nitrogen and phosphorus deficiency on 
flavonol accumulation in plant tissues. Plant, Cell \& Environment, 24(11): 1189-1197.

Vacant,V.(2015)The hand book of mites of economic plants identification, Bioecology and control pp 890.(uk:CABI puplishing)

Van Leeuwen, T., Berg, V.P., Nauen, R.,( \& ) Tirry, L., (2007).Organophosphate insecticides and acaricides antagonize by fenazate Toxicity through esterase inhibition in Tetranychus urticae .Pest management Science.63,(12):1172-1177.

Woisky, R., \& Salation, A . (1998). Analysis of propolis : some parameters and procedures for chemical quality control . Journal of Apicultural research. 37(2): 99-105. 